\title{
LIBERALISMO Y NEOCONSTITUCIONALISMO: LOS LENGUAJES DEL ESCEPTICISMO
}

\author{
Renato Garín*
}

RESUMEN: En torno al pensamiento de John Rawls el autor plantea una forma alternativa de comprender el derecho y la política. El argumento trata, fundamentalmente, de criticar la forma en que el liberalismo rawlsiano comprende lo político y, en seguida, mostrar como esa comprensión conduce al escepticismo institucional en el que hoy nos encontramos. Ello repercute en el rol que se le asigna a la Constitución Política y al catálogo de derechos fundamentales dentro de la democracia.

\section{PALABRAS CLAVE: J. Rawls - Derechos fundamentales - Liberalismo - Republicanismo.}

ABSTRACT: Around the thought of John Rawls, the author proposes an alternative approach to understanding law and politics. The argument tries, fundamentally, to criticize the way in which Rawlsian liberalism understands the political, and following that, show how this understanding drives to the institutional skepticism in which we find ourselves today. This has an impact in the role that is given to the political constitution and to the catalogue of fundamental Rights within democracy.

KEYWORDS: J. Rawls - Fundamental Rights - liberalism - republicanism.

Para nadie es un misterio que términos como "política" o "políticos" no gozan de buena reputación en la opinión pública. Numerosas encuestas muestran que, entre los diversos funcionarios públicos, los parlamentarios son los que presentan menos credibilidad y "la política" como expresión institucional resulta insatisfactoria a los ojos de los ciudadanos. Esa sensación térmica tiene, en algún sentido, un correlato evidente al apreciar que la democracia chilena se ha convertido en un ritual de contar votos cada cierto tiempo.

En este artículo quiero hacerme cargo de ese fantasma que ronda nuestra convivencia democrática y quiero mostrar que el descrédito de "la política" es en realidad una concepción errada de lo que la política es. Quiero hacer ese ejercicio desde la teoría política y pretendo mostrar cómo una diversa comprensión de lo político puede reformar a la política. Mi intención es presentar una forma de comprender lo político en oposición a lo que se denomina "liberalismo político" cuyo principal referente es, a mi entender, John Rawls. La importancia de Rawls no puede ser minimizada puesto que su Teoría de la Justicia y su posterior Liberalismo Político son las obras centrales del debate filosófico en los últimos años. Sin la obra

\footnotetext{
* Estudiante de la Escuela de Derecho, Universidad de Chile. Agradezco los comentarios al primer borrador de este texto que me formularon Alfredo Jocelyn-Holt y Pablo Ruiz-Tagle. Estoy en deuda con mis amigos que, pacientemente, se dieron el tiempo de discutir el argumento central. Además, tal y como los lectores de este ensayo, soportan todos mis errores
} 
de Rawls el debate entre comunitaristas y liberales no habría sido posible el trabajo de una gran cantidad de autores que dialogan con Rawls o proponen una diversa construcción de la justicia. Y sin Rawls, además, la filosofía política no encontraría una versión coherente y sistematizada de la forma en que el liberalismo concibe la democracia, los derechos fundamentales, lo político y la práctica jurídica. Intentaré mostrar que las consecuencias en lo público de este nuevo sentido común académico no son alentadoras y que las mismas no pueden ser pasadas por alto dado el surgimiento del neo-constitucionalismo, que en cierto sentido es tributario del liberalismo, que ha puesto en tela de juicio la distinción entre lo político y lo jurídico. Todas estas cuestiones tienen como punto de partida una cierta comprensión que maneja el liberalismo rawlsiano sobre la democracia y la igualdad que pone de relieve una forma de aproximarse a lo político y al derecho. Por esa arista del problema, entonces, habremos de comenzar.

\section{Liberalismo Político}

"There are many of us, and we disagree about justice". Hay muchos de nosotros y tenemos desacuerdos sobre lo justo. Así abre Jeremy Waldron su Law and Disagreement que resume, en la primera frase del libro, los dos componentes de lo político; pues la palabra política, como han recordado algunos autores ${ }^{2}$, tiene un doble origen. Por una parte política evoca a la "Polis", es decir, la unidad de agencia, el "nosotros" político y, por otra parte, política proviene de "Pólemos" que hace mención a los conflictos políticos existentes dentro de ese nosotros. Ese conflicto no versa acerca de la identidad de la comunidad política, es decir, nunca está en duda la unidad de agencia, esto es, en ningún momento peligra la polis, pero podemos imaginar conflictos políticos que sí traigan como consecuencia el peligro de la polis, como vimos en Chile la mañana del 11 de Septiembre de 1973. Esos conflictos son los que redefinen a la polis, cuando se ejerce el poder constituyente, el poder de constituir a la polis.

En sus trabajos Rawls intenta, justamente, dar solución a la coexistencia pacífica entre personas que no están de acuerdo acerca del bien o qué cuenta como “justo”. Y ese problema ha sido, por mucho tiempo, el tópico central que ha enfrentado el liberalismo en la segunda mitad del siglo XX. Por años la mejor respuesta que encontraba el liberalismo era la de Schumpeter ${ }^{3}$ quien concibe la democracia como modus procidendi en sus palabras, que es capaz de regular el conflicto entre diversas concepciones de la justicia. La democracia en el sentido de Schumpeter, a quien sigue Hayek y más tarde Guzmán, es meramente instrumental y resulta tan legítima como la monarquía o la aristocracia. Cristi explica la idea que maneja Schumpeter de una forma democrática de convivencia como:

\footnotetext{
${ }^{1}$ Waldron, J. Law and Disagreement. Oxford: Clarendon Press, 1999.1. No puedo pasar por alto lo notable y agudo que resulta Waldron en este texto y en The Dignity of legislation que lo muestran como uno de los pensadores de inevitable referencia en cualquier ensayo sobre filosofía política contemporánea.

${ }^{2}$ MoufFe, C. El retorno de lo politico. Barcelona, Paidós, 1999, p.14

${ }^{3}$ SChumpeter, J. Capitalismo, Socialismo y Democracia. New York, Harper and Row, 1942.
} 
"una competencia entre una pluralidad de grupos partidistas que luchan por recursos escasos y buscan imponer sus intereses particulares. El juego político se reduce a compromisos y transacciones que conforman espontáneamente un orden político. Condición necesaria para la preservación del pluralismo democrático es que lo grupos en competencia lo hagan en igualdad de condiciones. Solo así se logra un equilibrio entre la oferta y la demanda de bienes políticos ${ }^{4}$.

Esa descripción es la perspectiva generalmente aceptada de la democracia como forma procedimental y neutral en relación a cualquier conjunto de valores, "como simple método para tomar decisiones públicas" 5 . En otras palabras, la democracia sería una manera, entre varias otras, de asegurar que se tomen decisiones entre diversos grupos que tienen concepciones acerca de lo bueno o lo justo con anterioridad a concurrir al proceso político, de manera análoga a cómo los agentes concurren al mercado: el demandante sabe qué quiere comprar y a qué precio y el vendedor sabe qué quiere vender y a qué precio.

Rawls, en cambio, se muestra en contra de esta formulación del principio de neutralidad. El objetivo de Rawls es poner de manifiesto que una sociedad "bien ordenada" necesita un compromiso más profundo que un mero modus procidendi basado solamente en determinados procedimientos, i. e., elecciones de representantes. La estrategia de Rawls es plantear un consenso moral que permita a personas, con diversas concepciones de lo justo, vivir juntas bajo un marco común. En la introducción a Liberalismo Político Rawls formula el problema del siguiente modo:

“¿Cómo es posible que pueda existir a lo largo del tiempo una sociedad estable y justa de ciudadanos libres e iguales pero profundamente divididos por 'razonables' doctrinas religiosas, filosóficas y morales?

Para contestar su pregunta Rawls pretende dar con un núcleo central de concepciones en que personas razonables estén de acuerdo y que permitan la vida en comunidad y el no enfrentamiento bélico. En su búsqueda distingue entre doctrinas razonables contra aquellas que no lo son, de ahí su distinción entre un pluralismo "simple" y el pluralismo "razonable".

"Entiendo el liberalismo político como una doctrina que pertenece a la categoría de lo político. Se desenvuelve enteramente dentro de dicho dominio y no cuenta con nada fuera de él. La visión más familiar de la filosofía política es que sus conceptos, principios e ideales, y otros elementos se presentan como consecuencias de doctrinas comprehensivas [...]. Por contra, la filosofía política tal como la entiende el liberalismo político consiste en su mayor parte en diferentes concepciones políticas [...] consideradas como independientes [...]. El liberalismo político se abstiene de realizar afirmaciones acerca del dominio de concepciones

\footnotetext{
${ }^{4}$ CRISTI, R. El pensamiento político de Jaime Gurmán. Santiago, Lom, 2000. p.18.

${ }^{5}$ MoufFe, C. La paradoja democrática. Barcelona, Gedisa, 2003. p. 40.

${ }^{6}$ Rawls, J. Liberalismo Político. México, Fondo de Cultura Económica, 1997. p.18.
} 
comprehensivas excepto cuando se trata de concepciones irrazonables y que rechazan todas las variaciones de los elementos básicos de un sistema democrático. Esto es parte del dejar la filosofía tal como está7."

El criterio de razonabilidad, en Rawls, viene dado por aquello que no se opone a lo que Mouffe ha denominado "moralidad política"8. Nuestro autor lo explica del siguiente modo:

\begin{abstract}
"Más que definir directamente lo razonable, determinaré dos de sus aspectos como virtudes de las personas9. [...] Las personas son razonables cuando se muestran dispuestas a proponer principios y criterios en calidad de términos equitativos de cooperación, y a aceptarlos de buena gana siempre que se les asegure que los demás harán lo mismo ${ }^{10}[\ldots]$. El segundo aspecto básico [...] es la disposición a reconocer las cargas del juicio y a aceptar sus consecuencias a la hora de usar la razón pública en la tarea de orientar el legítimo ejercicio del poder político en un régimen constitucional ${ }^{11}$."
\end{abstract}

Es decir, en palabras de Rawls, las personas razonables son aquellas que

"han tomado conciencia de sus potencias morales en un grado suficiente para ser ciudadanos libres e iguales en un régimen constitucional, y que tienen un sólido deseo de atenerse a unos justos términos de cooperación y de ser miembros plenamente cooperadores de la sociedad ${ }^{12}$."

Lo anterior no hace más que devolver a fojas cero el problema. Rawls piensa que en esta distinción puede descartar ciertas concepciones que no son compatibles con el modelo democrático, i. e., que no son razonables. Pero no hace más que enunciar el dilema pues todo lo que necesitamos saber es qué cuenta como un "régimen constitucional" y qué cuenta como “justos términos de cooperación”. Una respuesta a eso es sostener que lo que el mismo Rawls propone como régimen constitucional y “justos términos de cooperación". Pero, evidentemente, bajo ese supuesto cualquier concepción política antiliberal sería excluida. ¿Qué ocurre, por ejemplo, con quienes no están de acuerdo con Rawls en que exista un Tribunal Constitucional? O, mejor aún, ¿Qué ocurre con los comunitaristas que piensan de forma distinta la justicia? En algún sentido nuestro autor cae en el error que pretende evitar pues termina definiendo "lo razonable" por la medida que el liberalismo entrega para hacerlo, es decir, lo razonable coincide con el liberalismo. Su propuesta, entonces, no es más que la

\footnotetext{
${ }^{7}$ RAwls, J. Liberalismo Político. México, Fondo de Cultura Económica, 1997. pp. 77-8

${ }^{8}$ MOUFFE, C. op.cit. (n. 5), p. 40s.

${ }^{9}$ RAWLS, J. op.cit. (n. 7), p. 79

${ }^{10}$ Ibid. p. 80

${ }^{11}$ Ibid. p.85.

12 RAWLS, J. op. cit. (n. 7), p. 55.
} 
expresión de una "decisión eminentemente política, no un requisito moral"13. Mi impresión, que coincide en los análisis, pero no en las conclusiones, del post-marxismo de Mouffe y Laclau $^{14}$, es que sí existe, siempre debe existir, un criterio que diferencia lo razonable de lo no razonable políticamente, es decir, aquellos con los que podemos dialogar de aquellos con lo que no existe otra opción que el enfrentamiento. Sin embargo, ese criterio no viene dado por una cuestión moral, sino porque concepciones extremadamente antagónicas no pueden convivir en una misma polis sin poner en cuestión la unidad de agencia de la misma polis o, para decirlo en los términos de Waldron, hay ciertos desacuerdos que no ponen en duda que seguimos siendo "nosotros", pero existen otro tipo de desacuerdos que, precisamente, atentan contra la unidad del "nosotros". Es eso lo que vemos todos los días en Colombia, México, España o a ratos en Chile con la "cuestión mapuche" y eso es, casi como ejemplo de laboratorio, lo que ocurrió la mañana del 11 de Septiembre de 1973. Rawls, pese a ello, no logra comprender ese tipo de desacuerdos porque no logra ver aquello a lo que el liberalismo es totalmente ciego: la dimensión constitutiva de lo político. Esto es lo que mueve a Rawls ha construir el consenso por superposición en oposición al public choice desarrollado antes por la teoría política norteamericana. Ambas posturas no logran ver la diferencia de niveles entre un conflicto político que pone en duda la unidad de agencia de la polis y otro que solamente se refiere a un conflicto político normal.

\section{Polemos}

Sabemos ya que política tiene dos raíces. Por un lado "polis", la unidad de agencia, que acarrea todo el problema del poder constituyente ${ }^{15}$, uno de los términos más jabonosos de la teoría política. Constituir la polis es constituir al agente político mediante un acto político, de ahí la paradoja análoga a lo que describe San Pablo al decir que "al comienzo era el verbo" o Goethe, en Fausto, “al comienzo era la acción”. La segunda raíz es "pólemos" que destaca la conflictividad de la acción política. En palabras de Atria;

"lo que es político en el sentido de polémico es que debemos actuar colectivamente, pese a que no estemos de acuerdo en qué curso de acción seguir ${ }^{16 "}$.

En seguida, en su trabajo Atria nos recuerda una distinción que realiza Schmitt que resulta central para dar luz al problema. Schmitt distingue entre "la forma y el modo" de una comunidad política y la "identidad" de la misma. Un conflicto político acerca de la "identidad" de una polis es lo que se denomina conflicto "reflexivo". El liberalismo rawlsiano comprende que ese conflicto reflexivo puede existir, esto es, su posibilidad, pero el modo en que se acerca

\footnotetext{
${ }^{13}$ Mouffe, C. op. cit. (n. 5), p. 42

${ }^{14}$ LaClau, E. y MOUFFe, C. Hegemonía y Estrategia Socialista. Madrid, Siglo XXI, 1997

${ }^{15}$ Véase la interesante discusión entre Cristi y Atria. La tesis del primero en CRISTI, Renato. El pensamiento político de Jaime Guzmán. La crítica del segundo en ATRIA, Fernando. "Sobre la soberanía y lo político". En: Revista Derecho y Humanidades, No 12, 2006 . La réplica de Cristi en Cristi, Renato Y Ruiz-TAgle, Pablo. La república en Chile. Santiago, Lom, 2007. Capítulo 7.

${ }^{16}$ ATRIA, F. op. cit. (n. 15), p. 38
} 
a él es negándolo. Para ello desplaza la sustancia del conflicto a la esfera privada, tratándolo como un mero desacuerdo entre ciudadanos acerca de cuestiones que no tienen implicancia política. Hay dos estrategias para llevar a cabo esa táctica, por un lado el public choice niega la autonomía de la esfera pública y entiende el conflicto político como un conflicto de mercado, esto es, entre partes sobre las cuales nunca hay duda sobre su identidad. La segunda estrategia, que prefiere Rawls, en cambio, prefiere excluir de la estructura básica de la sociedad todo lo que sea conflictivo, en particular las concepciones del bien y de la justicia de cada uno, lo que llama el consenso por superposición.

Rawls sostiene que si una sociedad está bien ordenada, el consenso se establece en torno a los principios de su teoría de la justicia como equidad. Dado que estos principios han sido escogidos mediante la construcción de la posición original con su "velo de ignorancia", tales principios satisfacen el principio liberal de ser aceptados por todos los ciudadanos racionales y razonables- ${ }^{17}$. Rawls pretende mostrar que hay un carácter moral en el consenso y no un mero interés personal de cada ciudadano. Nuestro autor parece creer que aun siendo imposible un acuerdo racional entre doctrinas generales de carácter moral, religioso y filosófico, es posible alcanzar dicho acuerdo en el campo político. Una vez que las doctrinas controvertidas han quedado relegadas al campo privado, es posible establecer en lo público un consenso fundando en la razón. Una vez alcanzado ese consenso sería imposible de deslegitimar y la única forma de "botarlo" sería atacarlo desde fuera, i. e., desde posiciones no razonables. Esto quiere decir que si se ha logrado instaurar una sociedad bien ordenada aquellos que han participado del consenso no tendrían ningún "derecho" a cuestionarla y solamente podría ser criticada, destruida, por personas no razonables.

No cabe duda de que Rawls considera que el total consenso entrecruzado o por superposición no podrá conseguirse nunca, pero sostiene que puede producirse una aproximación lo suficientemente satisfactoria. Lo que no ve Rawls es que su consenso liberal no hace más que eliminar todo componente político, en el sentido de polémico, de la vida pública. El concepto de justicia de Rawls es algo que reconocen los ciudadanos razonables y racionales que actúan conforme a lo que ese concepto de justicia manda. Y es probable, reconoce el liberalismo político, que los ciudadanos tengan concepciones muy diversas e incluso conflictivas acerca de lo bueno, pero esas cuestiones son "estrictamente privadas y no interfieren con su vida pública"18. Aquí salta a la vista una de las aristas más interesantes del pensamiento rawlsiano. Por una curiosa razón, todo lo que resultaba interesante en Teoría de la Justicia pasa a un segundo plano en Liberalismo Político. En la primera Rawls se interesó por plantear una idea metafísica de la persona, siguiendo a Kant, pero -dadas las criticas y dardoscambia de perspectiva en su última obra y no se ocupa ahora por cuestiones metafísicas sino por problemas políticos, es decir, se aleja de un liberalismo comprehensivo y se contenta con un liberalismo " meramente político". De este modo, dice Cristi describiendo la idea rawlsiana de lo político, "independiente de cómo se resuelva la cuestión metafísica, los ciudadanos, en cuanto sujetos políticos, son libres y esto quiere decir, en primer lugar"19:

\footnotetext{
${ }^{17}$ RAWLS, J. op.cit. (n. 7), p. 141.

18 Ibid.

${ }^{19}$ CRISTI, R. op.cit. (n. 15), p. 189
} 
"que tienen el derecho de ser considerados como personas independientes de, y no identificables con, ninguna concepción particular y su esquema de fines últimos ${ }^{20 "}$.

Cristi coloca el ejemplo de una persona que decide cambiar de religión. Ello, bajo la lupa de Rawls no significaría la alteración de su identidad pública sino un mero cambio en opciones privadas de vida.

En segundo lugar, los ciudadanos son libres "en el sentido de que son fuentes originales y auténticas de demandas válidas"21. Es indiferente, dice Cristi,

"el que esas demandas manifiesten ideales religiosos o morales, ideales patrióticos o meras preferencias. Su validez como demandas políticas no dice relación con la importancia de los bienes que afirman. El liberalismo político pone así entre paréntesis nuestras convicciones morales y religiosas 22 ".

Como intentaré mostrar en lo que sigue, lo que el liberalismo político de Rawls tiene de "político" es solamente el apellido. Y esto es así porque la teoría de Rawls descansa en la comprensión liberal de la igualdad, la libertad, el derecho y lo político. Según la versión rawlsiana, los ciudadanos necesitan, como personas libres e iguales, los mismos bienes, ya que sus concepciones de "lo bueno", por muy diversas que sean requieren todas de

"los mismos bienes primarios, esto es, los mismos derechos básicos, las mismas libertades y oportunidades, y los mismos medios multiuso, como los ingresos y la riqueza, todo ello completado por las mismas bases sociales de respeto propio ${ }^{23}$."

Así, lo que la concepción de "sociedad bien ordenada" de Rawls termina por eliminar es la lucha democrática entre "adversarios", esto es, entre quienes comparten la lealtad hacia los principios democráticos, pero defienden interpretaciones distintas respecto a lo que significar la "libertad", la "igualdad", la "vida o la "honra" en cada caso. Gracias a su juego de racionalidad y moralidad el liberalismo de Rawls quiere dar solución al dilema liberal: cómo eliminar a sus adversarios y seguir siendo al mismo tiempo neutral. Sin embargo, la estrategia de Rawls falla por donde pretende ganar pues, su liberalismo excluye todo elemento político de la política. El peligro es evidente pues cualquier desacuerdo termina por poner en duda la unidad de agencia de la polis al presentarse como una lucha entre enemigos. Esta es la razón por la que el liberalismo político, lejos de entender lo político, termina negándolo y pone en riesgo aquello que quiere solidificar, esto es, la convivencia democrática y hace imposible la distinción entre "adversarios" y "enemigos".

\footnotetext{
${ }^{20}$ Rawls, J. op.cit. (n. 7), p. 30.

${ }^{21}$ Ibid. p. 32.

${ }^{22}$ CRISTI, R. op.cit. (n. 15), p.190.

${ }^{23}$ RAwLS, J. op.cit. (n. 7), p.180.
} 


\section{Democracia y Liberalismo}

¿Qué hace liberales a los liberales? En otras palabras: ¿Dónde radica el punto central del liberalismo? La respuesta a esa pregunta la ha dado uno de los juristas y pensadores de la política más agudos, y menos comprendidos, del siglo XX: Carl Schmitt. Por muchas razones el pensamiento de Schmitt se ha visto tergiversado dada su militancia en el Partido Nazi durante la Segunda Guerra Mundial. Schmitt fue conocido como el Kronjurist de Hitler y sus ideas acerca del poder constituyente fueron utilizadas por el abogado de la Pontificia Universidad Católica, Jaime Guzmán, durante el proceso de creación de la Constitución de 198024. En lo que sigue no pretendo mostrar a Schmitt como un pensador republicano, no pretendo tampoco negar su paso por el nazismo, pero sí quiero usar sus ideas como arma de crítica contra el liberalismo rawlsiano.

Los liberales sostienen que todos los seres humanos, no importando el lugar donde viven o al país al que pertenecen, son iguales. Igualdad en el sentido de igualdad humana, que todos gozan de los mismos derechos humanos y de las mismas garantías frente a sus respectivos Estados. Este es el cordón umbilical del argumento liberal desde hace varios siglos: la primacía ontológica del sujeto ${ }^{25}$. Ello se manifiesta en el individualismo liberal que concibe el individuo como anterior a la comunidad, es decir, los individuos poseen una libertad en principio ilimitada que ceden, en parte, al Estado que tiene una libertad en principio limitada. Esta es la lógica del contractualismo que, como veremos, tiene una tensión inevitable con la idea de democracia.

Schmitt, uno de los antiliberales más famosos del siglo XX, plantea en el prefacio de su texto La Crisis de la Democracia Parlamentaria de 1926 la tesis de la homogeneidad como condición de cualquier democracia.

"Toda democracia real descansa en el principio de que no sólo son iguales los iguales, sino en el de que no recibirán un trato igual los desiguales. Por consiguiente, la democracia exige, en primer lugar homogeneidad, y en segundo lugar -si surge la necesidad- la eliminación o la erradicación de la heterogeneidad 26 ."

Esta afirmación bien podría ser descartada inmediatamente por el tinte racista que conlleva teniendo en consideración la evolución política personal de su autor. Sin embargo, considero que es posible llevar a cabo una lectura de esta afirmación que ponga de relieve una de las características centrales de la democracia que el liberalismo tiende a eliminar.

Schmitt sostiene que la "homogeneidad" es una idea central en la tradición democrática, en el sentido de que la democracia, como ejercicio político dentro de la polis, es

\footnotetext{
${ }^{24}$ Sobre Schmitt véase CRISTI, Renato. Carl Schmit and authoritarian liberalism. Véase también la obra de los profesores argentinos DOTTI, J Y PINTO, J. Carl Schmitt: su época y su pensamiento. Sobre el vínculo entre Guzmán y Schmitt véase CRISTI, Renato. op.cit. (n. 15), Véase adicionalmente ATRIA, Fernando. op.cit. (n. 15).

${ }^{25}$ Vid. SANDEL, M. Liberalism and the limits of Justice. Cambridge, Belknap, 1996.Particularmente en la introducción Sandel descompone el argumento liberal.

${ }^{26}$ SCHMitT, C. The Crisis of Parliamentary Democracy. Traducción de E. Kennedy. Cambridge, 1985. p. 9.
} 
llevada a cabo por los "iguales" que son iguales en virtud de una "sustancia común". De esta manera Schmitt niega el valor político de la igualdad abstracta liberal.

"La igualdad sólo es interesante y de inestimable valor político en la medida en que tenga sustancia, y en que, por esta razón, contenga al menos la posibilidad y el riesgo de la desigualdad ${ }^{27}$."

La igualdad liberal, entonces, no tiene ningún sentido político pues no permite diferenciar entre aquellos que pertenecen a la polis y aquellos que no pertenecen. Dicho en otros términos, la existencia de una polis alemana y una polis chilena dice que los alemanes son más iguales entre ellos de lo que es un chileno y dentro de los chilenos los chilenos somos más iguales entre nosotros que un alemán entre nosotros. La igualdad liberal, sin embargo, no proporciona un correlato posible de desigualdad.

"La igualdad de todas las personas en tanto personas no es democracia sino una cierta forma de liberalismo, no es una forma estatal sino una ética individualista humanitaria y una Weltanschaung. La moderna democracia de masas descansa en la confusa mezcla de ambas cosas. ${ }^{28 "}$

Nótese que esto no se traduce en la negación de la igualdad humana, sino que se niega su relevancia política. Nadie, por supuesto, estaría dispuesto a negar que los seres humanos somos iguales unos a otros, pero lo que interesa aquí no es ese sentido sino la igualdad política existente entre todos. Desde el punto de vista de Schmitt, cuando hablamos de igualdad debemos distinguir entre dos niveles de cosas. Por un lado la concepción liberal de la igualdad y, por otro, la idea democrática de igualdad. Según el primero las personas, en tanto personas, son todas iguales. La segunda, en cambio, vive de la posibilidad de distinguir entre quién pertenece a la polis y quién no, en nuestros términos, quién es ciudadano de un país y quién no.

$\mathrm{Y}$ esto es interesante pues para Schmitt el sujeto portador de lo político es el pueblo, pero el concepto de pueblo se constituye a sí mismo por medio del antagonismo político. Si hubiera un solo pueblo en el planeta, la noción de pueblo no existiría, de modo que el agente constitutivo de un pueblo no puede ser sino otro pueblo que, negando al primero, lo obliga a constituirse como pueblo y así sucesivamente ${ }^{29}$. Schmitt no es un humanista en el sentido liberal, y esa es una de las cuestiones que les resulta más difícil de entender a los liberales que buscan atacar a Schmitt, pues "humanidad excluye el concepto de enemigo"30 y, con ello, excluye el concepto de lo político. Esa igualdad democrática, que hoy conocemos como ciudadanía de un respectivo país, es para Schmitt la base de todas las demás formas de igualdad. Esta es la razón por la que el concepto central en la construcción teórica de Schmitt

\footnotetext{
${ }^{27}$ Ibid.

${ }^{28}$ Ibid. p. 13

${ }^{29}$ MiRES, F. Introducción a la politica. Santiago, Lom, 2000. p. 56.

${ }^{30}$ SchmitT, C. El concepto de lo político. Traducción de R. Agapito, Madrid, Alianza, 1998. p. 55
} 
no sea la de "humanidad" sino el de "pueblo". La democracia solamente puede existir para un "pueblo".

"En el ámbito de lo político, las personas no se ponen una frente a la otra en calidad de abstracciones, sino como personas provistas de un interés político y políticamente determinadas, como ciudadanos, gobernantes o gobernados, como aliados o como oponentes políticos en cualquier caso, por tanto, en función de categorías políticas. En la esfera de lo político, no puede abstraerse lo que es político y dejar únicamente la igualdad humana universal ${ }^{31}$."

Pero, ¿en virtud de qué son iguales aquellos que son iguales entre sí? La respuesta de Schmitt a esta pregunta es lo que se denomina "la fruta envenenada" de su teoría por ser una respuesta que, inequívocamente, lleva a una política de exclusión y exterminio racial. La unidad del agente político, es decir, la igualdad dentro de la polis, es, según Schmitt, natural, en el sentido de pre-política. Esto es diametralmente opuesto a la idea que maneja Hobbes, a quien tantas veces se relaciona con Schmitt, quien concibe la unidad de agencia, del Leviatán, como un hecho político, no natural. En Hobbes los seres humanos en estado natural no existen como "pueblo" sino como mera colección de individuos que, a fin de proteger parte de su libertad, ceden otra parte de ella al poder común.

Decía que el pueblo no es un dato natural, no puede serlo sin caer en el error con tinte racista de Schmitt. La existencia del pueblo, de la polis, es un dato político, es un acto político de existencia que se identifica con el poder constituyente. Sabemos ya que el poder constituyente lleva consigo la paradoja de la teoría constitucional que es que el sujeto político, el pueblo, comienza a existir por un acto político que él mismo lleva a cabo. Pero aún no encontramos respuesta a la pregunta antes planteada, es decir, si la igualdad de la polis no es un dato natural, entonces, ¿en virtud de qué son iguales los iguales? La única respuesta posible a esta pregunta, para no caer en el error de Schmitt, es sostener que la igualdad de la polis viene dada por una declaración política de igualdad. A esa declaración hoy en día le llamamos "derechos fundamentales" o, en el lenguaje de los estadounidenses, "verdades auto evidentes". El nacimiento de una comunidad política, por ejemplo de los norteamericanos en 1776, es de las cuestiones más poéticas de la teoría política pues da cuenta de cómo un agente político se da nacimiento a sí mismo. Y ese nacimiento es en virtud de ciertas verdades que nos definen políticamente y que nos hacen identificables como polis. Atria lo explica en un pasaje que merece ser citado in extenso:

"Pero por supuesto, al entender la frase "x sostiene y" como una afirmación de la existencia e identidad de x, tanto x como y se definen recíprocamente. Sostenemos estas verdades como auto evidentes, pero también: esas verdad definen quiénes somos, es decir, los que creemos en ellas. $\mathrm{Y}$ nótese que las verdades que sostenemos son auto-evidentes, es decir, "nosotros" creemos en ellas no porque hayamos sido convencidos por argumentos, sino porque se presentan

\footnotetext{
${ }^{31}$ Sснмітт, C. op. cit. (n. 26), p. 11.
} 
inmediatamente a nuestra razón. Esta última afirmación debe ser entendida en sentido político, no metafísico. Significa que con aquellos que las niegan, no es posible ningún argumento político; si su negativa amenaza nuestra existencia, serán entonces nuestros enemigos: "consideramos al resto de la humanidad Enemigos en la Guerra, en la Paz Amigos"32."

El enemigo en este contexto es el otro existencial. Es con quien, en el conflicto existencial, no hay lugar para la paz ni para la indiferencia. El otro está en el último lugar de la negación, al borde mismo de la guerra y es el que, por eso mismo, nos convierte en alguien diferente de él, o de ellos, es decir, en un nosotros. En breve y otra vez: aquellas verdades auto-evidentes que nos definen como polis nos constituyen políticamente y hacen posible que seamos iguales entre nosotros y distintos de otros. Esos otros, en contextos de paz, son nuestros amigos, pero en contextos de guerra no pueden sino ser nuestros enemigos pues nos niegan existencialmente. Pensemos, como ejemplo, en el enfrentamiento entre la URSS y EEUU durante la guerra fría. Ambos se negaban existencialmente pues ambos negaban una "verdad auto evidente" del otro, a través de los diversos modelos económicos que practicaban. Y eso es, a la vez, lo que enfrentó, al menos sustancialmente, a buena parte de occidente contra la Alemania Nazi de Hitler durante la Segunda Guerra Mundial: los nazis negaban lo sagrado de la vida de cada ser humano a través del genocidio judío que practicaban y ello los constituyó en nuestros enemigos y debimos enfrentarlos.

Los enemigos y los amigos son aquellos que están fuera de la polis, los adversarios, en cambio, son parte de "nosotros" pero, por la contingencia de lo político, tienen desacuerdos en torno a qué es justo o bueno en cada caso. Los adversarios comparten aquellas verdades auto evidentes, son parte de la polis y componen la agencia política, pero por diversos intereses conciben de forma distinta los conceptos que nos definen como comunidad política. Ese es el objetivo de las constituciones políticas: constituirnos políticamente.

Ese era el sentido institucional del constitucionalismo clásico: hacer posible lo político. Y lo hacía posible porque posibilitaba la existencia de un agente político, de un "nosotros", pero lo hacía posible también porque restringía las opciones de quien detentaba el poder: establecía en líneas generales la forma y el modo de existencia de la comunidad política, del nosotros. Ello posibilitaba, en base al constitucionalismo clásico, que los gobernantes no fueran tiranos, esto es, hacia posible el gobierno basado en la razón y no en el temor. Solamente a través de la existencia de una unidad de agencia política podemos actuar colectivamente a través de nuestros representantes y podemos estar, todos, pese a que tengamos desacuerdos políticos, i. e., pese a que seamos adversarios, unidos -como las páginas de un libro- en la Constitución Política. Eso es lo que Rawls no logra comprender: no entiende que el rol de la Constitución no es establecer derechos en sentido jurídico sino que es vincularnos como sujeto político. Es por eso que las constituciones tienen, en lo relevante a "derechos fundamentales" o "verdades auto evidentes", conceptos y no concepciones 33 . Que la Constitución chilena asegure "el derecho a la vida", "a la libertad" "a la igualdad" o a la "honra" es análogo a lo que Thomas Jefferson declarara como verdades auto-evidentes del

\footnotetext{
32 ATRIA, F. op. cit. (n. 15), p. 25.

${ }^{33}$ La distinción es de HART, H. The Concept of Law. Oxford, Clarendon Press, 2000.
} 
pueblo norteamericano, la libertad, la igualdad, la dignidad, la búsqueda de la felicidad. Pero esa afirmación no define qué es la libertad o la igualdad y ese es, precisamente, el valor de esas declaraciones: hacen posible que personas con diversas concepciones de la libertad o la dignidad se vean representadas en nuestro texto fundacional que nos constituye políticamente.

Hasta aquí hemos visto que el liberalismo político de Rawls no comprende el conflicto político entre adversarios por un doble motivo. Por un lado porque todo conflicto político lo relega al ámbito privado por una estrategia - en el caso de Rawls- de consenso por superposición o, en otros casos, de public choice y, por otro lado, porque no entiende la dimensión constitutiva de lo político y nunca se pregunta por la identidad del agente político. Eso lleva al liberalismo a no poder diferenciar entre adversarios y enemigos, es decir, entre quienes comparten la polis y quienes están fuera de ella. Y no lo logra porque la idea de igualdad que concibe el liberalismo no es política, no entrega un criterio de des-igualdad.

Desde lo que pretendo llamar una concepción republicana de lo político he señalado que los "derechos fundamentales" son aquello que nos permiten constituir la polis. Sin embargo, esta postura que resulta un lugar común a la luz del constitucionalismo clásico, que hacía posible lo político, choca de frente con el nuevo fantasma que recorre a la filosofía del derecho, la teoría política y la práctica jurídica en el mundo: el neo-constitucionalismo que pretende limitar normativamente lo político volviendo difusa la distinción entre lo político y lo jurídico.

\section{De Tortugas y Escorpiones}

En sus Discursos sobre la Primera Década de Tito Livio Maquiavelo sostiene que la república exige la virtud cívica, materializada como amor a la patria y a la constitución, como "principio de la acción de la comunidad política"34. Por "amor a la constitución" Maquiavelo no se está refiriendo al conjunto de normas de la Constitución, sino a la expresión de la polis, como vimos antes. Entiende que el requisito de existencia de la comunidad política es que sus integrantes no atenten contra ella, es decir, que se sientan ligados a la Constitución como una relación de amor: sentir que en la Constitución de la polis también están representados ellos. Cuando se pierde ese vínculo ocurre lo que ocurrió en Chile la mañana del 11 de Septiembre de 1973. El republicanismo es, históricamente, el correlato de esa virtud cívica entendida como "amor a la Constitución”. Oscar Godoy lo explica del siguiente modo:

"El liberalismo, contrastado con los republicanismos, se nos aparece como algo abstracto. Y ello se atribuye al hecho de que los teóricos del liberalismo, como Locke por ejemplo, nos proponen un ser humano pre-social, que se rige por leyes naturales, y que no tiene arraigo en ninguna sociedad histórica y concreta. En cambio, la teoría republicana apela a un ser humano inserto en una sociedad histórica, enraizado en una comunidad concreta, partícipe de las ideas y valores colectivos. El amor a la patria y a la constitución significa ese arraigo ${ }^{35}$."

\footnotetext{
34 Godoy, O. "Republicanismo, Liberalismo y Democracia”. En: Estudios Públicos, 2005. pp. 242-256.

${ }^{35}$ Ibid.
} 
La Constitución como lo que hace posible lo político en el sentido de constituir la polis. Pero el neo-constitucionalismo no ve lo mismo en la Constitución, esta "corriente de pensamiento"36 -como la ha denominado Pozzolo- se opone al positivismo jurídico del siglo XIX y propone la eficacia normativa de la Constitución, es decir, que la Constitución valga como una ley. Y aquí, nótese, no estamos hablando de la parte orgánica de las constituciones, no se trata de si la duración del mandato presidencial o la cantidad de Senadores deba operar o no como una ley, porque obviamente la respuesta es sí, sino si los "derechos fundamentales" pueden ser aplicables en un Tribunal.

El neo-constitucionalismo en algún sentido es hijo del terror. Tras la Segunda Guerra Mundial, dados los atropellos y el genocidio practicado por los totalitarismos europeos y las tiranías latinoamericanas, se ha vuelto un lugar común creer que el derecho puede servir para prevenir el terror e impedir que se reproduzcan las imágenes que vimos en la Alemania Nazi o en la Unión Soviética de Stalin. Todo ello parte de una curiosa descripción de la democracia: el gobierno de la mayoría con el respeto de los derechos de las minorías. Esa definición ha dado a luz a lo que la teoría política identifica como "la paradoja de la democracia liberal" 37 que consiste en que debe gobernar la mayoría pero, a la vez, se deben respetar los derechos de la minoría. Y Rawls no está lejos de esa fórmula pues está a favor de la revisión judicial de las decisiones legislativas. En primer lugar se coloca a la Constitución a la cabeza del sistema jurídico, como el tronco desde el cual todo se deriva ${ }^{38}$. Luego se dice que los derechos fundamentales de las personas son límites a las decisiones mayoritarias en contextos democráticos pues, de otra forma, estaríamos frente a una dictadura de la mayoría. Por último se sostiene que debe existir tal límite, y debe existir revisión judicial de las decisiones legislativas, pues debemos prevenir la instauración de regímenes totalitarios o tiránicos.

Dos reconocidos autores, Renato Cristi y Pablo Ruiz-Tagle, que parecen identificarse con el neo-constitucionalismo, lo describen del siguiente modo:

"El constitucionalismo implica esencialmente un intento de establecer el imperio de la ley con el fin de limitar el poder político, específicamente por medio de las constituciones escritas. (...) Pero en el siglo XX, bajo el impacto de la experiencia totalitaria en Europa, el constitucionalismo se ha centrado en la tarea de limitar el poder legislativo a través del establecimiento de un sistema de control judicial que quede en manos del poder judicial ${ }^{39} . "$.

\footnotetext{
${ }^{36}$ Pozzolo, S. “Neoconstitucionalismo y especificidad de la interpretación constitucional.” En: Doxa, No 21, p. 339

37 Ese es el tema que inspira el libro de MOUfFe, C. La paradoja de la Democracia Liberal. Curiosamente, pese a que esta autora construye a lo largo de su argumentación una sólida crítica a la forma en que el liberalismo comprende la democracia, termina concluyendo que la paradoja de la democracia liberal no es un defecto o un punto ciego, sino que es una virtud. Y eso es sencillamente incompatible con su post-marxismo pues termina por concebir una mezcla entre marxismo y liberalismo que, en sus conclusiones, resulta incomprensible. Y lo es porque defiende una idea de democracia radical y, a la vez, trata como virtud lo que pretende criticar.

${ }^{38}$ Comúnmente suele decirse que el sistema normativo es una pirámide, lo que, según algunos, viene desde Kelsen. Pero eso es incorrecto, en Kelsen -y en general en todos los autores de sistema normativo- la metáfora correcta no es una pirámide sino un árbol. Para el ideal neo-constitucionalista, entonces, la Constitución es el tronco del árbol y cada ley una de muchas ramas.

${ }^{39}$ CRISTI, Renato y RuiZ-TAgle, Pablo. op. cit. (n. 15), pp. 29-30.
} 
Nótese, en primer lugar, que el párrafo toma la postura neo-constitucional de limitar el poder político y no de hacerlo posible como describe el constitucionalismo clásico. En seguida defienden la idea del control judicial de las decisiones democráticas con referencia al totalitarismo Europeo de mitades del siglo pasado. A este respecto debe hacerse una mención necesaria a la idea de "limitar" el poder. Por supuesto que el constitucionalismo clásico, el que por ejemplo defienden los padres fundadores en El Federalista, contempla una forma en que aquellos que son designados nuestros representantes - parlamentarios o Presidente de la República- no se transformen en piratas que abusan del poder que se les ha otorgado y ese control es la separación de poderes. La existencia del Parlamento, del Presidente y de los Tribunales hace posible que exista lo político pues permite que la soberanía popular no sea "capturada" por quienes han sido elegidos. En ningún momento la revisión judicial de las decisiones democráticas fue un postulado del constitucionalismo clásico, pero desde la decisión del juez John Marshall, Presidente de la Corte Suprema Norteamericana, en el caso Marbury v. Madison esa idea se ha vuelto un lugar común. Ruiz-Tagle y Cristi describen la decisión de Marshall del siguiente modo:

"La idea de Marshall es concederle a la Constitución un status jurídico superior, porque constituye la ley suprema en virtud de ser promulgada por el pueblo. El papel de la Corte es proteger las decisiones constitucionales fundantes frente al efecto erosionador que conlleva la legislación normal ${ }^{40}$."

Lo primero que debemos tener presente es que en este caso el juez Marshal operó con competencias que ni la Constitución ni ninguna ley le otorgaban para revisar la constitucionalidad de una ley. El fundamento de su decisión fue la idea de que si la Constitución era la ley suprema entonces los jueces que decidían alguna causa debían pronunciarse acerca de la inconstitucionalidad de una ley. Nótese, en seguida, que los profesores Cristi y Ruiz-Tagle conciben a la legislación normal como portadora de un efecto erosionador de la legislación constitucional. Ese efecto erosionador, sostienen, debe ser compensado a través de la revisión judicial de las decisiones democráticas en un Tribunal Constitucional (como ocurre en Europa) o en la Corte Suprema (como es en Estados Unidos). De aquí surgen dos preguntas interesantes que pueden servir para poner de relieve el dogma neo-constitucional. La primera es que, aún si aceptáramos que la Constitución es una "ley fundamental', ¿dice algo eso acerca de quién debe velar por la constitucionalidad de las leyes? Y la segunda es ¿Qué es lo que se "erosiona" a través de la legislación normal?

La respuesta a la primera pregunta es negativa, nada dice la supremacía de la Constitución acerca de quién debe ser el custodio de ella. Bien podríamos decir que la supremacía de la Constitución podría ser encargada a un Tribunal Constitucional o a la Corte Suprema, pero nada impide que le otorguemos ese control al parlamento ${ }^{41}$. Entonces, diría el neo-constitucionalista, ¿qué sentido tendría darle la potestad de controlar a quien queremos controlar? Desde una posición que promueva el autogobierno ese argumento no hace sentido. Si la Constitución es la expresión de lo que somos como polis, entonces no hay ninguna

${ }^{40}$ Ibid. p. 37. Cursivas agregadas

${ }^{41}$ Ver el interesante trabajo de Troper, M."Poder Judicial y Democracia”. En: Isonomía, No 18, 2003. 
razón para que el control de las leyes no lo hagamos también nosotros a través de nuestros representantes. Y esto, obviamente, implica la disolución del control de constitucionalidad porque si una mayoría aprueba una ley entonces no tendría ningún sentido que esa misma mayoría rechazara su propia ley porque la considera inconstitucional. Y la razón fundamental de ello es que la Constitución es, o debe ser, tan amplia en su redacción que la idea de inconstitucionalidad de una ley debe ser una cuestión extremadamente marginal en lo relativo a "derechos fundamentales". Como he marcado reiteradamente antes, la Constitución, en los derechos fundamentales, tiene una redacción que hace mención a conceptos y no concepciones por lo que si una mayoría dicta una ley que toca temas relativos a la "vida", como es el caso del aborto, no puede haber ahí ninguna inconstitucionalidad pues aquella ley no sería más que una concepción del concepto que contiene la Constitución.

Entonces es posible imaginar una nueva réplica de parte de los neoconstitucionalistas: hagamos que la Constitución tenga concepciones y no conceptos, porque ahí sí sería susceptible de ser aplicada como una norma. Pero si fuera así la Constitución no tendría ningún sentido político pues quienes no estén de acuerdo con esas concepciones expuestas en la Constitución no podrían sentirse parte de la polis y, en vez de constituirnos políticamente, ese texto no haría más que dividirnos.

Vemos que el problema salta a la vista. Como la Constitución contiene conceptos y no concepciones no puede ser aplicable jurídicamente pues el contenido de esos conceptos es político. Es evidentemente político el sentido que le demos a la "libertad", "igualdad", "vida" u "honra" por lo que la decisión que se tome en base a ellos será nada más que la expresión política del juez o jueces que la tomen. Cuando el Tribunal Constitucional en Chile debe pronunciarse acerca de una solicitud de la constitucionalidad de una ley que despenaliza el aborto por ir en contra del artículo 19 número 1 que asegura la "vida" no puede decidir ese caso sino teniendo como base sus concepciones políticas. Entonces todo el proceso de deliberación pública que se lleva a cabo en el Parlamento se vuelve inútil y es la deliberación dentro del Tribunal Constitucional la que termina por decidir una ley que nosotros nos hemos dado en virtud del autogobierno de la polis. Nótese la forma en que lo describen Ruiz-Tagle y Cristi:

"La revisión judicial se ha hecho tan extendida que la interpretación constitucional no se guía ya por la agenda legislativa, sino que se determina por el espíritu de la adjudicación. “

En algún sentido podríamos decir que en Chile la última palabra, la que importa, en materia legislativa no la tienen los representantes de la mayoría sino los integrantes del Tribunal Constitucional y son ellos los únicos parlamentarios que no han obtenido votos. Este liberalismo neo-constitucional no hace sino atentar contra la idea de la legislación que uno de los padres del liberalismo, John Locke, defendió ${ }^{42}$ pues coloca al legislador bajo el control de un órgano que termina decidiendo, bajo nada más que concepciones políticas, qué ley es constitucional y qué ley no lo es, es decir, nos imponen la polis que ellos quieren construir y

${ }^{42}$ Véase WALDron, J. The Dignity of legislation (n.1), p. 63 
no la que hemos decidido construir. La idea del autogobierno no es más que esa: que somos capaces de deliberar y establecer las leyes y que serán ellas quienes gobiernen y no hombres y mujeres.

En base a eso podemos contestar la segunda pregunta propuesta más arriba: no hay nada que se erosione mediante la legislación normal. Ello pues la ley no hace sino especificar el sentido de la constitución. El valor de la legislación, entonces, es materializar contingentemente la promesa que nos hicieramos en la constitución.

\section{La Tiranía de la Mayoría}

Una vez que los neo-constitucionalistas se enfrentan a estos argumentos suelen decir que hay una respuesta histórica. Esa respuesta histórica es que los totalitarismos del siglo XX nos han enseñado que es recomendable tener frenos institucionales para cuando la mayoría se "emborrache". Pero por supuesto este argumento, que suele ser el último que se esgrime, equivoca el camino. Es una falacia evidente creer que una norma sirve para evitar la tiranía de la mayoría o para impedir que los regímenes democráticos se transformen en totalitarismos. Mirar el caso chileno es útil: no hay ninguna buena razón para creer que una norma de cualquier jerarquía pudiera impedir que Pinochet diera el golpe de Estado la mañana del 11 de Septiembre de $1973^{43}$. Y esto es iluminador para entender el sentido de este artículo: hay cuestiones, y esta es una de ellas, que el derecho no puede impedir.

El problema de la tiranía de la mayoría es mal comprendido. No se entiende que si se erige un gobierno totalitario no habrá ninguna norma que impida que lleven a cabo su plan de acción. En contextos normales, en gobiernos democráticos, la idea de una tiranía de la mayoría es comúnmente sobre dimensionado. Así lo cree -por ejemplo- un popular cientista político:

"En este momento es importante establecer claramente que el concepto "tiranía de la mayoría" no debe hacer pensar que las mayorías electorales puedan tiranizar. Una cosa son las mayorías concretas de pequeños grupos "reales" (estas pueden muy bien ser tiránicas) y otra totalmente diferente son las mayorías electorales. En este último sentido nos referimos a colectividades extensas y dispersas, y así, "mayoría" significa, como de costumbre, agregaciones efímeras que se forman y se disuelven elección tras elección. Es verdad que también pueden existir "mayorías de masas" estables y en estado de coagulación, las cuales exigen que la mayoría de una población electoral esté constituida por individuos identificados (de clase, raza o partido) que estén verdadera e intensamente, identificados. En las democracias occidentales no es así casi nunca (sucede a las minorías, no a la mayoría). Por lo tanto, las mayorías de masas que sostengan y promuevan una tiranía de la mayoría, en el sentido constitucional del término, son demasiado improbables y también difíciles de lograr ${ }^{44}$."

\footnotetext{
${ }^{43}$ Véase ISRAEL, R. La Democracia que se perdió entre todos. Santiago, Mare Nostrum, 2006.

${ }^{44}$ SARTORI, G. ¿Qué es la Democracia?. Santiago, Taurus, 2003. p. 139.
} 
Pero, entonces, ¿quién puede impedir que las mayorías se emborrachen y pasen a llevar a las minorías? El derecho, evidentemente, no pues si la mayoría está borracha nada impedirá que se reformen las normas que les son incómodas o, sencillamente, pasarlas a llevar también. La única instancia en la que podemos evitar la violencia y el terror es la política y para ello la política debe comprenderse como la mejor forma de encontrarnos. Hannah Arendt comprendió de la mejor manera posible aquello al entender que al ser clausurados los espacios políticos solo es posible que se imponga el terror total ${ }^{45}$. Además, y este es uno de los más fuertes argumentos de Waldron ${ }^{46}$, hay una evidente tensión al concebir al individuo como un ser autónomo, libre y responsable de sí mismo y, a la vez, pensar que el individuo actuando en grupo es capaz de perder la razón y pasar a llevar a los demás. Cuando se pretende despolitizar las cuestiones es cuando se corre el riesgo que temen los neo-constitucionalistas. Fernando Mires lo expresa del siguiente modo:

"Con la burocratización del Estado termina la política como cosa pública, antagónica y polémica. No obstante, su espacio continúa abierto, aunque vacío. Ahora bien, es en ese vacío de poder y de política donde a veces hace su entrada triunfal el demagogo iluminado que, apoyado en la mecanizada e impersonal burocracia, entra a dominar sobre los destinos de un país a punta de balas y cuchillos. Esa -la pasiva burocracia que llegó a contabilizar millones de cadáveres, a incluirlos en ítems, a catalogarlos en archivos y despacharlos en largos informes, y que después se dejó seducir obscenamente por los aullidos del Fuhrer- fue la que despolitizó (y con ello policializó) al Estado del país de Weber a fin de que su utopía se convirtiera en realidad...."

Esto no lo logra comprender el neo-constitucionalismo. Ellos ven al derecho como una herramienta adecuada para limitar lo político e impedir el terror. La experiencia histórica, dicen, muestra justamente aquello. Pero no notan que la experiencia histórica muestra lo contrario: que los totalitarismos y el terror están dispuestos a pasar por encima de cualquier cosa, seres humanos o normas, en pos de su utopía. Y aquí no sirve establecer algún criterio para determinar cuándo el pueblo está borracho pues la "borrachez del pueblo" es por definición, también un tema político. Basta con pensar en Chile entre los años 70 y 73 y nos daremos cuenta que una persona de derecha aseguraría que el pueblo estaba borracho, no así alguien de izquierda.

Pero el neo-constitucionalismo es algo más que una doctrina incapaz de comprender lo político, es también el mejor aliado del liberalismo político de la segunda mitad del siglo XX y reproduce, con su acción, una antigua fábula:

Una vez una tortuga se encontró con un escorpión a la orilla de un río. El escorpión le pidió a la tortuga que lo cruzara en su caparazón hacia la otra orilla. La tortuga dudó y se negó pues temía que el escorpión la picara. El escorpión le

45 ARENDT, H. Los Orígenes del Totalitarismo. Traducción de G. Solana, Madrid, Alianza, 1987.

${ }^{46}$ WALdRON, J. Law and Disagreement. (n. 1). 
prometió no hacerlo y, tras mucho meditarlo, la tortuga accedió. El escorpión se subió al caparazón y la tortuga se lanzó al agua con el escorpión encima. Cuando iban a la mitad del río el escorpión picó a la tortuga:

-Pero idiota, dijo la tortuga, ¿Por qué me picaste? Ahora nos ahogaremos los dos.

-Es que es mi naturaleza dijo el escorpión.

Esta fábula es notablemente útil para este caso. El neo-constitucionalismo sube en su caparazón a los derechos fundamentales e intenta cruzarlos dede la orilla de lo político a la orilla del derecho, pero algo ocurre a mitad de camino y termina naufragando, entre el derecho y la política, sin poder aferrarse a ninguna de las dos orillas. Y cuando se pregunta por qué ha naufragado los derechos fundamentales le contestan lo obvio: la naturaleza de lo político impide cruzar el río con éxito.

Ahora es interesante preguntarse por qué el neo-constitucionalismo quiere cruzar el río entre lo político y el derecho. Y para ello debemos volver a la idea de la Constitución como constitución política de la polis contra la idea normativa de la Constitución. Oscar Godoy no distingue esto:

“Claro está, la virtud cívica del republicanismo nos propone la supremacía del amor a la patria y a la constitución por sobre los intereses particulares y el liberalismo concibe al todo de la comunidad política como un garante de la vida, la libertad y los bienes de los individuos que la componen. Y si hay algún amor en el liberalismo, éste es a la constitución ${ }^{47}$."

Godoy no nota la distinción entre la idea republicana de la constitución como punto de partida de la polis y la idea liberal de la constitución como garantía o límite. Piensa que el "amor a la constitución" de ambos se refiere a lo mismo. Esto sirve para ver con claridad el telón de fondo de estos problemas: la diferente concepción del liberalismo y del republicanismo de lo político. Giovanni Sartori explica la idea liberal:

"El hecho es que la solución liberal-constitucional del problema del poder se funda sobre el derecho, y que el derecho es límite, un conjunto de límites limitantes. Y la idea de legalidad limita, 'in primis', el poder popular ${ }^{48}$."

Vemos que el liberalismo comprende al derecho como externo a la política, como un límite. Por su parte la tradición republicana concibe a la constitución como una relación interna con lo político, lo hace posible.

\footnotetext{
${ }^{47}$ Godoy, O. op.cit. (n. 34), p. 255

${ }^{48}$ SARTORI, G. op.cit. (n. 44), p. 227
} 
"El republicanismo es una teoría sobre cómo la soberanía política encuentra expresión en el derecho. El derecho, sostienen los republicanos, hace posible la soberanía popular facilitándole reglas constitucionales como el vehículo o el "hogar" de la deliberación política ${ }^{49}$."

Entonces ahora podemos cerrar el círculo que abrimos más arriba. El conflicto político, decíamos, es trasladado por parte del liberalismo rawlsiano, en todo aquello que es conflictivo -polémico, pólemos- al ámbito privado por una estrategia de consenso por superposición que hace irrelevante políticamente las concepciones del bien de cada ciudadano. Es similar a la estrategia del public choice, pero con ciertos matices que la configuran como una teoría independiente. Pero el liberalismo, en cualquiera de sus facciones requiere de algún mecanismo que asegure que esa estrategia funcione. Dicho en otras palabras: el liberalismo busca algo con qué atar a la política para que la política no se autodestruya, o, en un ejemplo, el liberalismo busca algo para evitar que lo político se decida de formas violentas como vimos en Chile hace más de 30 años. Entonces mira a su alrededor en busca de una soga que permita atar la política y la encuentra en el neo-constitucionalismo, en los derechos fundamentales y en la revisión judicial.

El liberalismo neo-constitucional nos deja a mitad de camino. Quita de la política lo que por definición debiera ser decidido políticamente (qué es la igualdad, la libertad o la vida en cada caso) y, además, amenaza con dejarnos sin derecho pues lo vuelve políticamente controvertido. Ya lo vaticinaba Honoré:

"En algunos países, como los Estados Unidos, se intenta destruir la autonomía del discurso jurídico y reducir las cuestiones jurídicas a cuestiones en las cuales cualquier tipo de consideración social, política o moral es relevante ${ }^{50}$."

La advertencia de Honoré es la crónica de una tragedia anunciada. Es el día a día en la práctica jurídica en que, cada vez más, se le pide a los jueces que fallen sobre cuestiones que ninguna norma dispone. Poner a jueces a decidir causas en base a cuestiones que nadie ha consagrado en normas es opresivo: juzga a las partes no según "sus" normas sino según lo que el juez cree que es pertinente aplicar ${ }^{51}$. Ruiz-Tagle, proponiendo una forma alternativa de interpretación constitucional que se enfrente a las, así denominadas, "doctrinas pontificias", sostiene que su construcción

"supone (...) un rechazo del método intuitivo y de la adopción de jerarquías injustificadas respecto de los derechos. Si admite algún grado de preeminencia entre derechos constitucionales, se exige una justificación histórica o política, o

\footnotetext{
${ }^{49}$ Christodoulidis, E. Law and Reflexive Politics, Dordrecht: Kluwer, 1998, p. 10.

${ }^{50}$ Honoré, T. "Legal Reasoning in Rome and Today". En; Cambrian Law Review, 1973. 58-76. 93

${ }^{51}$ Este es, exactamente, el problema que tiene la llamada "eficacia horizontal" de los derechos fundamentales y, además, la misma crítica que puede hacerse a la escuela del Law and Economics que pretende aplicar criterios de microeconomía en las decisiones judiciales.
} 
por lo menos un sometimiento a las exigencias formales expuestas por Rawls (...) También supone que la inclusión de elementos morales, religiosos, políticos o económicos fundacionales, deben mencionarse en forma expresa (...) Por su parte, la delimitación busca fijar los límites de los contornos externos de los derechos sin afectar el núcleo de los mismos o su esencia ${ }^{52}$."

Ruiz-Tagle intenta una forma de concebir los derechos fundamentales que haga posible que sean aplicables jurídicamente, pero en su intento hace que la advertencia de Honoré se vuelva realidad. No hay forma de entender los derechos fundamentales sin una referencia ajena al derecho. Entonces comenzamos a tener jueces más preocupados de elementos morales, religiosos, políticos o económicos fundacionales que de aplicar las normas. Y en seguida Ruiz-Tagle intenta dar solución al problema de la abstracción de los derechos fundamentales conceptos y no concepciones- declarando que existe una "esencia" o "núcleo" en cada derecho, pero eso no hace más que reproducir el problema con otros términos pues ahora nos preguntamos por cuál es el núcleo o la esencia del derecho.

El lenguaje de los derechos, como lo ha descrito Mary Ann Glendon, ha llevado a que las cuestiones políticas por excelencia se hayan transformado en materias judiciales. Ronald Dworkin es uno de los autores que más énfasis le ha dado a la función judicial como un moderador político ${ }^{53}$. No es de extrañar que Dworkin, y todos los liberales norteamericanos, tome esta posición pues, mal que mal,

“el creciente predominio del poder jurídico también debe entenderse en el contexto del debilitamiento de la esfera política democrática pública en la que debería tener lugar la confrontación agonísitica. Dada la creciente imposibilidad de concebir los problemas de la sociedad de una forma políticamente adecuada, existe una marcada tendencia a privilegiar el campo jurídico y a esperar que el derecho proporcione las soluciones a todos los tipos de conflictos ${ }^{54}$."

Dworkin es uno de aquellos que cree que los problemas políticos como el desempleo, la educación, la censura, la libertad de asociación o la contaminación ambiental quedan mejor resueltas si interviene un juez, con tal que interprete la constitución haciendo referencia al principio de igualdad política. Peor aún, hay una creciente cultura jurídica que cree que en los tribunales los problemas encuentran mejor solución porque están ajenos a la contingencia política, es decir, que la política contamina lo que está en juego y lo salpica de intereses partidistas. Así todos los problemas sociales, todos los antagonismos, se enfocan desde la óptica jurídica en la forma de derechos. No hay indicador más revelador

\footnotetext{
${ }^{52}$ Cristi, R. y Ruiz-Tagle, P. op. cit. (n. 15), p. 262-3. El destacado es mío.

${ }^{53}$ Dworkin, R. Law's Empire. Londres: Fontana, 1986. En especial véase la tesis que maneja Dworkin del "juez Hércules". Véase adicionalmente DwORKIN, R. Taking rights seriously. Cambridge, Harvard University Press, 1978.

${ }^{54}$ Mouffe, C. op. cit. (n. 5), p.128.
} 
"de la medida en que los conceptos jurídicos han penetrado el discurso popular y político que nuestra creciente tendencia a referirnos a lo que es más importante para nosotros en función de derechos, y a caracterizar casi todas las controversias sociales como un choque de derechos ${ }^{55}$."

Y esto está lejos de ser algo positivo. Aquí no estamos juzgando si los abogados, expertos en reconducir cualquier conflicto a "derechos fundamentales" y a presentar recursos de protección están o no equivocados sino si acaso la democracia gana o pierde. Mary Ann Glendon da un par de argumentos que es útil atender:

"Nuestro lenguaje sobre los derechos, con su carácter absolutista, estimula expectativas poco realistas, intensifica los conflictos sociales e inhibe el diálogo que podría conducir al consenso, al ajuste o al menos a encontrar un terreno común. Al no pronunciarse acerca de las responsabilidades, parece tolerar que se acepten los beneficios que acarrea vivir en un Estado democrático de bienestar social, sin aceptar los correspondientes deberes personales y cívicos. En su implacable individualismo, estimula un ambiente poco acogedor para los fracasados de la sociedad, y ello sitúa sistemáticamente en desventaja a los agentes protectores y a los dependientes, jóvenes y viejos. En su despreocupación por la sociedad civil, debilita los principales semilleros de virtudes cívicas y personales. En su insularidad, les cierra la puerta a ayudas que podrían llegar a ser importantes para el proceso de auto-corrección. Todos estos rasgos fomentan la simple afirmación por sobre la argumentación razonada. ${ }^{5{ }^{\prime \prime}}$

Nótese que hablábamos, más arriba, de la constitución como lo que nos hace ser "nosotros". Pero este lenguaje de los derechos, con una fuerte carga anti-política, hace que la constitución se transforme en un arma jurídica, un enfrentamiento en virtud de aquello que se supone nos hace hombres y mujeres que comparten una comunidad. Seguramente aquellos, los liberales neo-constitucionalistas, que no comprenden el ámbito constitutivo de la constitución no se alarmarán ante estos argumentos. Dirán que el derecho no se trata solamente de una cuestión técnica y de razonamiento jurídico sino también, y fundamentalmente, de cuestiones políticas y morales. No hay nada nuevo en esto,

"Aquellos que han renunciado a la política común y a los procesos legislativos no se sentirán afligidos si las controversias más importantes quedan en manos de los tribunales ${ }^{57}$."

Por supuesto que el liberalismo norteamericano ha buscado respuestas a estas objeciones. Y es útil notar que los problemas aquí descritos no han encontrado mayor

\footnotetext{
${ }^{55}$ GLENDON, M. "El Lenguaje de los Derechos”. En: Estudios Públicos, № 70, 1998. 76-147

${ }^{56}$ Ibid. p. 94

${ }^{57}$ Ibid. p. 68
} 
solución sobretodo en lo referente a la "dificultad contramayoritaria". Así, al menos, lo relata Gabriela Alonso

\begin{abstract}
"Durante las últimas décadas, la "dificultad contramayoritaria" ha fascinado a los teóricos constitucionales. Dicho brevemente, la dificultad contramayoritaria es el problema de cómo una sociedad democrática puede justificar autorizar a los jueces (que no han sido elegidos popularmente y no están sujetos a la responsabilidad de dar cuenta de sus actos ante el pueblo) para invalidar la elección de ciertos cursos de acción política por parte de legisladores elegidos democráticamente ${ }^{58}$."
\end{abstract}

En seguida Alonso nos da cuenta de las diferentes teorías que se han formulado para "resolver" la dificultad contramayoritaria y por qué todas, en algún sentido, fracasan. Así es cómo la idea "fundacionalista" defendida por Dworkin"s, la "tesis intermedia" de John Hart Ely ${ }^{60}$ y la "estrategia del precompromiso" 61 pretenden solucionar el problema de la tortuga pensando que la dificultad no está en la naturaleza del escorpión sino en el agua y pretenden colocar un dique a la corriente del río pensando que pueden salvar a la tortuga con eso pero, por supuesto, no logran dar con una solución al problema porque no lo entienden. Bruce Ackerman en cambio, entiende el problema pero pretende concebir una teoría que haga que el problema desaparezca, es decir, pretende hacer que el escorpión deje de ser tal. Esta teoría es interesante pues, en mucho tiempo, no se había presentado una comprensión tan sistemática y coherente de un sistema institucional, en este caso el estadounidense ${ }^{62}$. En palabras de Alonso,

"Ackerman propone disolver, antes que resolver, la dificultad contramayoritaria: el control de constitucionalidad no entraña un problema fundamental de legitimidad ya que, lejos de oponerse o constituir una alternativa a la práctica democrática, es en sí mismo una forma de práctica democrática (...) la historia y práctica constitucionales en Estados Unidos son más adecuadamente caracterizadas por una distinción entre "política normal" y "política constitucional", es decir, por una teoría democrática dualista. La primera fase se distingue por el predominio de tres actitudes disposicionales: apatía, ignorancia y egoísmo. El rasgo distintivo de la política constitucional está dado, en cambio, por juicios populares "considerados" (o reflexivos) acerca de "los derechos de los ciudadanos y los intereses permanentes de la comunidad" 63 ."

\footnotetext{
58 Introducción a Ackerman, B. La Politica del Diálogo Liberal. Barcelona, Gedisa, 1999. Traducción de G. Alonso, p.9

${ }^{59}$ Ver Dworkin, R. Law's Empire (n.59). También disponible en una curiosa traducción como El Imperio de la Justicia.

${ }^{60}$ ELY, John. Democracy and Distrut. Cambridge, Harvard University Press, 1981.

${ }^{61}$ La mejor defensa de esta tesis se encuentra en HOLMES, S. Precommitment and the Paradox of Democracy. J.Elster y R. Slagstad, eds. 1988

${ }^{62}$ Las obras centrales de este autor son ACKerman, B. We the People: Foundations. Cambridge: Harvard University Press, 1998

y ACKerman, B. We the people: Transformations. Cambridge, Harvard University Press, 1998

${ }^{63}$ Introducción a ACKERMAN, B. op. cit. (n. 58), p. 12
} 
Ackerman nos invita a distinguir entre dos visiones. Por un lado el monismo, que solamente trataría como normas en sentido jurídico aquellas que han sido producto de la legislación normal representativa y el dualismo en que también tienen el carácter de normas jurídicas aquellas que son producto de todo el pueblo en momentos de participación, los momentos constitucionales ${ }^{64}$. Entonces Ackerman nos entrega ciertos criterios para distinguir un verdadero momento constitucional exitoso de un conflicto político normal:

"De acuerdo con Ackerman, éstos son cuatro: (a) un alegado mandato por uno de los tres poderes nacionales conducente a la promulgación de legislación transformadora; (b) la resistencia por otro poder de la nación, produciendo una situación de impasse entre los poderes; (c) una elección crítica en la que el pueblo tiene la oportunidad de deliberar y elegir entre posiciones constitucionales opuestas (la presidencia plebiscitaria); y (d) un "giro en el tiempo" por el cual el poder nacional inicialmente reticente manifiesta su aquiescencia con la voluntad popular, seguido de la codificación del momento constitucional por la Corte Suprema a través de una serie de opiniones transformadoras ${ }^{65}$."

En primer lugar, Ackerman reconoce la posibilidad del conflicto reflexivo, es decir, reconoce que hay ciertos momentos en que la polis decide su identidad. Pero en seguida Ackerman pretende establecer criterios normativos para regular los momentos constitucionales. $\mathrm{Y}$ eso es evidentemente contradictorio pues los momentos políticos reflexivos son por definición momentos en que cualquier manifestación normativa para la acción del pueblo resulta fútil. Pierde de vista Ackerman que el pueblo en contextos reflexivos siempre opera por interposita persona, es decir, por representantes que se abrogan la representación del pueblo. Su éxito o fracaso no viene dado por cumplir o no con los criterios de Ackerman sino con el grado de fuerza política que logran reunir. Por ejemplo: es imposible negar que en 1973 comienza un momento reflexivo de nuestra polis y es imposible afirmar, también, que se cumplen los criterios de Ackerman. Y esto nos lleva a un nuevo problema: es absolutamente inconsistente creer que la Corte Suprema, a través de "una serie de opiniones transformadoras", pueda tener alguna ingerencia en las decisiones reflexivas sobre la polis. Carlos Santiago Nino expresa esta objeción a Ackerman:

"Con respecto a la justificación del control judicial de constitucionalidad, la visión dualista es problemática ya que no ofrece razones para que "la voluntad del pueblo" deba ser preservada por funcionarios contramayoritarios y no por aquellos que se encuentran más cerca de las preferencias de las mayorías actuales ${ }^{66}, "$

\footnotetext{
${ }^{64}$ Esta es una de las ideas que inspira el análisis en CRisTi, R. Y RuiZ-TAGLE, P. op. cit. (n. 15), Véase especialmente el capítulo uno.

${ }^{65}$ Introducción a ACKERMAN, B. op. cit. (n. 58), p. 14-5

${ }^{66}$ Nino, Carlos Santiago. La Constitución de la Democracia Deliberativa. Barcelona, Gedisa, 1997. p. 147
} 
En algún sentido Nino nos muestra el punto crucial: definir qué cuenta como un "momento reflexivo" es una cuestión política en sí misma. No hay espacio conceptual para una posición objetiva que nos permita distinguir una pretensión de la otra. Ello supone que podemos concebir a un observador interno del proceso político y, a la vez, neutral respecto del mismo. Esto es trágico para el neo-constitucionalismo pues su construcción teórica termina descansando en la mera discreción de los agentes. Pero, por alguna razón, estos problemas se han ido marginando del debate público y suelen ser tratados como meros problemas académicos.

\section{Lo Público y lo Político}

El punto más discutido en los últimos años en torno al republicanismo y el liberalismo es si acaso la participación política tiene o no un valor intrínseco. Esa es la preocupación, por ejemplo, de Cristi ${ }^{67}$ que intenta mostrar que el republicanismo es concebible como una tercera vía - "lugar de acercamiento y encuentro"68 en sus palabrasentre el liberalismo y el comunitarismo. El mismo Rawls, en Liberalismo Político, cree que la participación no puede ser un valor en sí mismo, pues, como todo liberal, niega la posibilidad de que los individuos lleguen a estar de acuerdo en el valor intrínseco de algo, en particular de la participación política ${ }^{69}$. Esa es también la discusión que han sostenido Pettit y Sandel y que ha recordado las distinciones entre republicanismo neo-ateniense y republicanismo neoromano ${ }^{70}$. Sin embargo, mi impresión es que el debate no ha dado con el punto relevante. Los autores han discurrido lo suficiente acerca del valor intrínseco de la participación como para poner de relieve que la médula del asunto no descansa ahí.

La idea de la autonomía de lo público, es decir, que la política es el único medio de canalizar lo político es central. Hay aquí dos dimensiones en juego, por un lado lo político que es la dimensión del antagonismo que es inherente a las relaciones humanas, antagonismo que se puede presentar de diversas formas y en distintos tipos de relaciones sociales. La política, en cambio, se refiere al conjunto de prácticas, discursos e instituciones que regulan la vida en sociedad y está cruzada por la dimensión antagonista de lo político. El problema del antagonismo en las cuestiones humanas no es nada nuevo, desde los primeros filósofos se ha reconocido como uno de los temas centrales y es en Hegel donde mejor se aprecia la idea del antagonismo -formulado como una "apetencia"- a lo largo de la historia71. Pero el punto aquí no es discutir acerca de sí es el antagonismo el motor de la historia humana, como sí lo hace Hegel, sino de entender que es la política la mejor forma de canalizar lo político.

Esa forma de canalizar pasa por comprender la dimensión de lo político como un inexorable antagonismo y a la política como la mejor manera de "domesticar"72 ese

\footnotetext{
${ }^{67}$ Cristi, Renato y Ruiz-Tagle, Pablo. op. cit. (n. 15). Capítulo 14.

${ }^{68}$ Ibid. p. 381

${ }^{69}$ RAWLS, J. op. cit. (n. 7). p. $207 \mathrm{~s}$

${ }^{70}$ Véase SAnDel, M. Democracy's Discontent. Cambridge, Belknap, 1996. y PeTTit, Philip. Republicanism. Oxford, Clarendon Press, 1997.

${ }^{71}$ Se ha argumentado que ese es el tema central en La Fenomenología del Espiritu. Véase adicionalmente PEREZ, C. Sobre Hegel. Santiago, Palidonia, 2006.

${ }^{72}$ La expresión es de MoufFe, C. op. cit. (n. 5), p. 114.
} 
antagonismo. Es por eso que Schmitt, cuando busca caracterizar lo político, encuentra la distinción básica en la noción de amigos y enemigos.

"La distinción política específica, aquella a la que pueden reconducirse todas las acciones y motivos políticos, es la distinción de amigo y enemigo. Lo que ésta proporciona no es desde luego una definición exhaustiva de lo político, ni una descripción de su contenido, pero si una determinación de su concepto en el sentido de un criterio $^{73}$."

Lo que la polis hace posible es que nuestros enemigos pasan a ser nuestros adversarios pues no hay una negación existencial entre nosotros. Y esto no es una reproducción del estado de naturaleza de Hobbes pues aquí la cuestión no es que cada hombre es el lobo de cada hombre, sino que los seres humanos nos agrupamos en torno a objetivos comunes a los cuales otros también aspiran u oponerse. De ahí que la idea de Aristóteles, que el hombre es un ser naturalmente político, pueda ser reentendida: es condición natural a la humanidad el antagonismo. Es la posibilidad del enfrentamiento bélico lo que da vida a la política. La política vive de la posibilidad de la guerra y de evitarla ${ }^{74}$. Pero la política no se trata de solucionar los antagonismos sino darles otro carácter: convertir los antagonismos en agonismos. Esta idea, de que la política permite que los antagonismos sean agonismos es sumamente antigua, pero igualmente olvidada. Hannah Arendt ha sido una de las autoras que nos ha recordado que el paso del antagonismo al agonismo

"pasó a ser el prototipo de la acción en la antigüedad griega e influyó, bajo la forma del llamado espíritu agonal, en el apasionado impulso de mostrar el propio yo midiéndolo en pugna con otro, que sustenta el concepto de la política prevaleciente en las ciudades-Estado ${ }^{75}$."

Tanto Arendt como Simone Weil han tomado como referencia los relatos homéricos sobre la guerra de Troya para explicar el origen y el sentido de la política ${ }^{76}$ y quizás sea útil, para comprender lo que está en juego, tener a la vista esos argumentos. Lo que a ambas autoras les llama la atención es que la Guerra de Troya tiene la dimensión de una guerra fundante, la primera guerra que conocemos, que destruyó una ciudad, pero que posibilitó en seguida la fundación de otras ciudades sobre sus cenizas. Es esa doble dimensión, la del antagonismo destruyendo una polis, y haciendo posible otras polis es lo que ven ambas autoras en Homero y de ahí explican el origen de la política. Un historiador de Grecia relata el "comienzo tras el fin" -el agonismo tras la guerra- como un desarrollo, el progreso de algo que está en curso:

\footnotetext{
${ }^{73}$ SCHMITT, C. op. cit. (n. 30).p. 55.

${ }^{74}$ De ahí que no sea extraño que la segunda palabra más mencionada en la obra de Schmitt después de "política" sea "guerra". MeIR, H. Carl Schmitt, Leo Strauss and The Concept of political. Chicago, The University of Chicago Press, 1995. Traducción de J. Harvey.

75 Arendt, H. La Condición Humana. Barcelona, Paidós, 1993. Traducción de M. Cruz y R. Gil., p. 217.

${ }^{76}$ Véase Espósito, R. El Origen de la Política. ¿Hannah Arendt o Simone Weil?. Barcelona, Paidós, 1999.
} 


\begin{abstract}
"Volviendo otra vez a Homero, veremos que en todo lo agonal no hay más que un principio infantil del desarrollo posterior. Aunque ya existen todas las especies de luchas, todavía no llegan a determinar y llenar la vida de los héroes, porque éstos tienen otras cosas que hacer delante de Ilión ${ }^{77}$."
\end{abstract}

Este es un punto interesante pues muestra la inexorable relación y oposición entre guerra y política en que el "doble origen" de pólemos y pólis parece unificarse en la idea de "agón", de hacer posible que la guerra deje de ser tal y se especifique como acción política. Espósito sostiene que se trata

"de una especificación de gran importancia, ya que al subrayar la relevancia, e incluso el carácter constitutivo, del elemento de la visibilidad en el ámbito de la política, muestra el último, o acaso primer, significado del origen pre-político de la política. Ésta es fuente de luz - la escena de la batalla está inundada de luz, se desarrolla siempre en pleno día, incluso al llegar la noche porque es una noche que preludia el nuevo día de la política. Del mismo modo que su relación con la pólis, extrínseca e intrínseca a un tiempo, es exactamente la misma que se da entre la luz y lo que ésta ilumina: distinto de ella, pero por ella hecho visible. El espacio de la política es el lugar en que la acción de los hombres aparece literalmente al mundo ${ }^{78}$."

Hasta ahí pareciera ser que la versión arendtiana del origen de la política es perfectamente poética, pero Arendt incluye un elemento en su análisis y es que la pólis como ideal griego fracasó:

"Mientras la pólis griega estuvo impregnada del espíritu agonal siguió siendo una forma aristocrática de gobierno, y no una oligarquía en la que el poder está en manos de una minoría. Los elementos aristocráticos, la pasión por la distinción y el individualismo extremo que la acompaña, llevaron finalmente a las póleis a la ruina, porque hicieron casi imposible sus alianzas ${ }^{79}$."

El problema de la pólis era que el ánimo aristocrático atentaba contra la unidad de la misma y la solución a ese problema no lo encuentra Arendt en Grecia sino en Roma. Es ahí donde es posible que la política se reencuentre en su doble origen -destrucción y fundaciónsin la "deuda y la culpa" 80 que en Grecia no se ha logrado expiar. Esa culpa es haber destruido Troya y no tener la distancia suficiente como para hacer justicia acerca de los troyanos. Por eso, dice Arendt,

\footnotetext{
${ }_{77}$ BurCKHARDT, J. Historia de la Cultura Griega. Barcelona, Iberia, 1974. p. 133-4.

${ }^{78}$ ESPÓSITO, R. op. cit. (n. 76), p. 48-9.

${ }^{79}$ ARENDT, H. Karl Marx and the Tradition of Western Political Thought. p.55.

${ }^{80}$ EsPÓsITO, R. op. cit. (n. 76), p. 56
} 
"es tan importante que la guerra de Troya, repetida sobre suelo italiano, a la que el pueblo romano remontaba su existencia política e histórica, no finalizara a su vez con una aniquilación de los vencidos, sino con una alianza y un tratado. No se trataba de atizar otra vez las llamas para invertir el desenlace, sino de concebir un nuevo desenlace para esas llamas ${ }^{81}$."

Arendt remarca repetidas veces el profundo significado constructivo, fundacional que tiene el incendio, la guerra. La diferencia que ve ella es que en Roma la luminosidad no viene dada por la apertura de un nuevo espacio - la política- sino por la luz de la lex, el derecho romano. Creer, en cambio, que son las normas lo que impiden que el conflicto político se vuelva bélico es no comprender lo que Arendt tan bien entendía: que la violencia está inserta en la política desde su fundación y que es la política lo único que permite evitar la violencia.

\section{Ardiente Paciencia: El Retorno de la Politica}

Comencé este artículo diciendo que hay una evidente crisis de la política como expresión institucional. Hay quienes creen que el republicanismo es una salida a esa crisis. Ciertos autores que revisan el republicanismo creen que el punto central del mismo es el énfasis en la participación, sin embargo, mi impresión es que el republicanismo es una defensa de la política para canalizar lo político y la participación no es más que una consecuencia obvia de ello. Pero nadie puede objetar que la idea de la política como agonismo y espacio de encuentro se ha vuelto difusa y frecuentemente puesta en duda. Sucede que las instituciones públicas son presa de una nueva actitud y de una nueva autocomprensión: el escepticismo. Ya no creemos en que ellas puedan unificar nuestros intereses, sino que son los vehículos mediante los cuales unos se imponen a otros. El escepticismo como enfoque institucional ha traído como consecuencia la tecnocracia y la asunción del discurso de los derechos como formas de canalizar los conflictos. Ello no es sino una negación de la esperanza fundacional que debe recorrer la política.

Sabemos que el conflicto político, la dimensión antagónica de la condición humana, es consustancial al pluralismo. La gran novedad que tiene la democracia es que el conflicto político está legitimado no así la posibilidad de suprimirlo autoritariamente. Pero eso no implica creer que la democracia se trata de construir constantes consensos y que el conflicto político normal debe ser evitado. El consenso básico de una sociedad democrática se basa en no atentar contra la unidad de la pólis, contra aquello que nos hace ser "nosotros".

Lamentablemente esa idea es comúnmente mal entendida, la política se ha transformado en una especie de gerencia en que solamente nos ocupamos de "solucionar los problemas de la gente" y cualquier conflicto político es tratado como mera "politiquería" y demagogia. Se ha transformado a la política en una actividad vacía que se aleja de las ideologías y las identidades políticas para abrazar otras formas de identificación. No hay mayor salida a ello que contestar institucionalmente con discursos históricos radicados en la

${ }^{81}$ Arendt, H. ¿Qué es la Política?. Traducción de R. Sala, Barcelona, Paidós, 1997. p. 118 
confianza. Confianza ya no en aquello que parece oprimirnos sino confianza en nuestra propia habilidad para encausar lo político.

\section{Ardiente Paciencia: El Fin de lo Politico}

Pero una actitud no escéptica de lo público es, comúnmente, considerada ingenua. Hoy pareciera que no cabe sino esperar un milagro para transformar la esfera pública y quitarla de las manos de los pasillos que la consumen. Pero esperar milagros es, también, una cuestión política. Hannah Arendt lo vio de forma inmejorable:

"Por lo tanto, si esperar milagros es un rasgo del callejón sin salida a que ha ido a parar nuestro mundo, de ninguna manera esta esperanza nos saca del ámbito político originario. Si el sentido de la política es la libertad, es en este espacio -y no en ningún otro- donde tenemos el derecho a esperar milagros. No porque creamos en ellos sino porque los hombres, en la medida en que pueden actuar, son capaces de llevar a cabo lo improbable e imprevisible y de llevarlo a cabo continuamente, lo sepan o no. La pregunta de si la política tiene todavía algún sentido, aun cuando acabe en la fe en milagros -y ¿dónde debería acabar, si no?- nos conduce inevitablemente de nuevo a la pregunta por el sentido de la política ${ }^{82}$."

Y esta es una idea que no solamente está presente en la teoría política, también la ha visto la poesía, como hermosamente lo escribiera Rimbaud: A la aurora, armados de una ardiente paciencia, entraremos en las espléndidas ciudades.

Armados de una ardiente paciencia lograremos hacer que los antagonismos desaparezcan, ese es el sentido profundo que debe tener la esperanza en la política. Eso debe llevar a que creamos, de nuevo, en la política como forma de canalizar lo político y de hacer posible la vida en comunidad. Pero no estoy hablando aquí de un optimismo ciego y cándido de creer que en la política está la solución a todos los problemas y el aseguramiento de la paz perpetua. La verdad es justamente lo contrario, dedicarse, como llama Weber, "profesionalmente" a la política debe ser la actividad que más responsabilidad acarrea pues lo que está en juego no es, como creen algunos, la popularidad de un Presidente o tener poder, sino cuidar la pólis e impedir que el antagonismo la destruya. Y esa es una lección especialmente importante para nosotros, los chilenos, en vista de lo que ha ocurrido en nuestro país en los últimos años. Que la política no se trata solamente de "solucionar problemas de la gente" y que los "derechos fundamentales" son algo mucho más trascendental que armas jurídicas puede llevarnos a volver a creer en lo público. Sobretodo en estos tiempos de "transición política" en que todavía no entendemos muy bien qué está en juego. Quizás, un reencantamiento con lo público haga posible que esta densa nube de apatía política que se ha posado sobre nuestra pólis se disipe y que vuelvan a brillar en nuestro horizonte las espléndidas ciudades.

82 Arendt, H. ¿Qué es la Política?. Traducción de R. Sala, Barcelona, Paidós, 1997 p. 66. 


\section{REFERENCIAS BIBLIOGRAFICAS.}

Ackerman, B. La Política del Diálogo Liberal. Barcelona, Gedisa, 1999. Traducción de G. Alonso.

-We the People: Foundations. Cambridge, Harvard University Press, 1998 We the People: Trasnformations. Cambridge, Harvard University Press, 1998

ARENDT, H. Eichman en Jerusalén: un estudio sobre la banalidad del mal. Barcelona, Lumen, 1967. . Karl Marx and the Tradition of Western Political Thought. New York, HC, 1953. . La Condición Humana. Barcelona, Paidós, 1993. Traducción de M. Cruz y R. Gil. . Los Orígenes del Totalitarismo. Madrid, Alianza, 1987. Traducción de G. Solana . Sobre la Revolución. Madrid, Alianza, 1988. Traducción de P. Bravo - ¿Qué es la Política?. Barcelona, Paidós, 1997. Traducción de R. Sala.

Atria, F. El Derecho y la Contingencia de lo Político en Revista Doxa, número 28, 2006. 2008. . "Sobre la Soberanía y lo Político" en Revista Derecho y Humanidades, número 13,

BEITZ, C. Political Theory and Internacional Relations. Princeton, 1974.

BurCKHARDT, J. Historia de la Cultura Griega. Barcelona, Iberia, 1974.

Christodoulidis, E. Law and Reflexive Politics. Dordrecht, Kluwer, 1998.

CRISTI, R. Carl Schmit and authoritarian liberalism.Cardiff, University of Wales Press, 1998. . El pensamiento político de Jaime Guzmán. Santiago, Lom, 2000.

CRISTI, R. Y Ruiz-TAgle, P. La República en Chile. Santiago, Lom, 2007

DotTI, J. Y PINTO, J. Carl Schmitt: su época y su pensamiento. Buenos Aires, Eudeba, 2003.

DwORKIN, R. El Imperio de la Justicia. Barcelona, Gedisa, 1999. . Law's Empire. Londres, Fontana, 1986. Taking rights seriously. Cambridge, Harvard University Press, 1978

ELY, J. Democracy and Distrut. Cambridge, Harvard University Press, 1981.

EsPósito, R. El Origen de la Política. ¿Hannah Arendt o Simone Weill. Barcelona, Paidós, 1999. Freud, S. Die Verneinung. Frankfurt, Fisher, 1993.

GARIN, R. Hacia las Grandes Alamedas en Revista Derecho y Humanidades, número 13, 2008. Glendon, M. "El Lenguaje de los Derechos” en Revista Estudios Públicos, número 70, 1998. Godoy, O. "Republicanismo, Liberalismo y Democracia" en Revista Estudios Públicos, número 99, 2005.

Hamilton, Madison Y Jay. El Federalista. México, Fondo de Cultura Económica, 1982. HART, H. The Concept of Law. Oxford, Clarendon Press, 2000. 
Carrió.

. El Concepto de Derecho. Buenos Aires, Abeledo-Perrot, 1963. Traducción de G.

HAYEK, F. Camino de Servidumbre. Madrid, Siglo XXI, 2000.

HobBes, T. Leviatán. México, Fondo de Cultura Económica, 2000.

HOHFELD, W. Conceptos Juridicos Fundamentales. México: Fontamara, 2001.

Holmes, S. Precommitment and the Paradox of Democracy en Constitucionalism and Democracy, J. ELSTER y r. Slagstad, eds. 1988.

HONORÉ, T. Legal Reasoning in Rome and Today en Cambrian Law Review, 1973.

IsRael, R. Chile 1970-1973: La Democracia Que Se Perdió Entre Todos. Santiago, Mare Nostrum, 2006.

Jocelyn-Holt, A. Historia General de Chile. Los Césares Perdidos. Santiago, Sudamericana, 2004.

LAClau, E. Y MOUfFE, C. Hegemonía y Estrategia Socialista. Madrid, Siglo XXI, 1997.

LEFORT, C. Democracy and Political Theory. Oxford, Oxford University Pres, 1988.

MeIR, H. Carl Schmitt and Leo Strauss: The Hidden Dialogue. Chicago, The University of Chicago Press, 1995. Traducción de J. Harvey.

Mires, F. Introducción a la Política. Santiago, Lom, 2000.

Montesquieu, L.Del espiritu de las leyes. Buenos Aires, Heliasta, 1984.

Moreiras, A. Linea de Sombra. El No Sujeto de lo Político. Santiago, Palidonia, 2006.

Mouffe, C. El Retorno de lo Político. Barcelona, Paidós, 1999. - La Paradoja Democrática. Barcelona, Gedisa, 2003.

Nino, C. La Constitución de la Democracia Deliberativa. Barcelona, Gedisa, 1997.

Nozick, R. Anarquía, Estado y Utopía. México, Fondo de Cultura Económica, 2001.

Peces BArbA, G. Curso de Derechos Fundamentales. Teoría General. Madrid, Carlos III, 1999.

PETTIT, P. Republicanism: A theory of Freedom and Goverment. Oxford, Clarendon Press, 1997.

Perez, C. Sobre Hegel. Santiago, Palidonia, 2006.

Portales, F. Los Mitos de la Democracia Chilena. Santiago: Catalonia, 2004.

Pozzolo., S "Neoconstitucionalismo y especificidad de la interpretación constitucional” en Revista Doxa, número 21, 1998.

RAwls, J. A Theory of Justice. Cambridge, Belknap, 1972.

. Liberalismo Político. México, Fondo de Cultura Económica, 1997.

Ross, A. Sobre el Derecho y la Justicia. Buenos Aires, Eudeba, 1994.

Rubenfeld, J. Freedom and Time. New Haven, Yale University Press, 2001.

Ruiz-TAgLe, P. Derecho, Justicia y Libertad. México, Fontamara, 2002.

SARTORI, G. ¿Qué es la Democracia? Buenos Aires, Taurus, 2003.

SAndel, M. Democracy's Discontent. América in Search of a Public Philosophy. Cambridge, Belknap, 1996.

Schmitт, C. El Concepto de lo Político. Madrid, Alianza, 1998. Traducción de R. Agapito.

- Teología Política. Buenos Aires, Struhart y Cía, 1998.

. Teoría de la Constitución. Madrid, Alianza, 1992. 
Kennedy.

The Crisis of Parliamentary Democracy. Cambridge, 1985. Traducción de E.

SCHUMPETER, J. Capitalism, Socialism and Democracy. New York, Harper and Row, 1942.

Tocqueville, A. La democracia en América. México, Fondo de Cultura Económica, 1963.

Troper, M. "Poder Judicial y Democracia” en Revista Isonomía, número 18, 2003.

WALDRON, J. Law and Disagreement. Oxford, Clarendon Press, 1999.

The dignity of legislation. Cambridge, Cambridge University Press, 1999.

WALzer, M. Las Esferas de la Justicia. México, Fondo de Cultura Económica, 1996.

Weber, M. El Político y el Cientifico. Buenos Aires, Prometeo, 2003. 